\title{
A Feasibility Study of SCADA Implementation at an Indonesian Oil Company
}

\author{
${ }^{1}$ Hence Tungkagi, ${ }^{2}$ Jenry Doan Saragih, ${ }^{3}$ Rizky Dwi Prayogo Lubis, ${ }^{4}$ Ahmad Syamil \\ ${ }^{1234}$ Binus Business School, Bina Nusantara University, Indonesia \\ Email Korespondensi: hence.tungkagi@binus.ac.id; jenry.saragih@binus.ac.id; \\ rizky.lubis@binus.ac.id; asyamil@binus.edu
}

\begin{abstract}
The implementation of Supervisory Control and Data Acquisition (SCADA) will make an activity more efficient because it will help control operation and production processes; control can be applied appropriately and at any time (real-time). This process will undoubtedly help the company to get maximum benefits. In 2020, the world oil price was very volatile and had touched a negative level. It is predicted that the uncertainty and low oil price will continue in the next few years. PT Pertamina Hulu Energi - Offshore South East Sumatra (PHE OSES), an Indonesian national company, plans to fully apply the SCADA system in its operational and production areas, because currently most of the PHE OSES areas still use the manual system. SCADA's estimated investment value of USD 8.6 million is a major investment for the company amidst the uncertainty of oil prices. Therefore, this project must get attention starting from the preparation, installation and implementation stages. In this article, economic analysis, cost \& benefit analysis, and sensitivity test to factors that can affect economic value will be carried out. An analysis will also be carried out in terms of change management. All of these analyzes will answer whether the implementation of SCADA is feasible or not. The result of this research show that this project is feasible to be implemented in PHE OSES, it meets the capital budgeting criteria and has benefit to cost ratio larger than one. Oil price and oil losses recovery are the most affecting factors in the project's feasibility. Company must do training, socialization, and hiring of experts play the vital role in the success of this project.
\end{abstract}

Keywords: SCADA, Feasibility Study, Economic Analysis, Cost \& Benefit Analysis, Change Management, Forces Field Analysis

\section{INTRODUCTION}

Supervisory Control and Data Acquisition (SCADA) is a control system that focuses more on supervisory levels (Daneels \& Salter, 1999). SCADA is a combination of telemetry and data acquisition. SCADA includes data collection, data transfer to the control center server, providing the necessary analysis and control, then displaying the information to the monitor layer to be viewed by the operator (Bailey \& Wright, 2003).

At this time, oil and gas companies strive to increase production by making efficiency one of the primary focuses to reduce the company's operational costs. SCADA is one of the IT-based technology products that management uses to control operation and production. Oil and gas exploration and production companies will continue to increase productivity through integrated operations.
Getting accurate and timely information and data is the key to success in the oil and gas industry. Management requires operational data from each production field to monitor equipment maintenance, make activity planning and maintenance, coordinate with logistics and other parties to ensure the operation process and production running wells. In this case, the management will use the SCADA system's data information to calculate production costs, assist in decision-making, and calculate the benefits.

The implementation of the current SCADA system in PT Pertamina Hulu Energi - Offshore South East Sumatera (PHE OSES), an Indonesian state-owned company, was not implemented thoroughly. SCADA systems were only installed in processing areas on some production wells. PHE OSES plans to implement the SCADA system fully and integrate all operating and production facilities. The SCADA implementation 
project in full at PHE OSES is a pilot project in the upstream environment of PT. Pertamina (Persero). Therefore, it is necessary to conduct research reviewed from the economic and change management side to provide recommendations to management on SCADA investment decision-making.

Thus, the questions that will be discussed in this research are:

1. Can full-field SCADA implementation investment in PHE OSES provide benefits for the company (based on capital budgeting criteria and cost \& benefit analysis)?

2. What are the dominant factors affecting the economy of SCADA implementation projects?

3. What is the analysis of change management related to the SCADA investment plan?

The general purpose of this research is to provide a feasibility evaluation of SCADA investment conducted by PHE OSES to increase the company's profit and transform the data information system from a manual system to SCADA technology system (real-time).

The analyses to be used are economic analysis, cost $\&$ benefit analysis, and change management. Economic analysis in this research is used to determine if the SCADA investment fulfills the capital budgeting criteria, and sensitivity analysis is used to ascertain which factors can impact these capital budgeting criteria. Cost and benefit analysis in this study will determine the influence of the operating costs of PHE OSES by comparing the estimated cost of SCADA projects with the benefits obtained after implementing SCADA, which will help management in making better decisions in the future. Change management is a process of updating the organization's direction, structure, and ability to face changes. The implementation of the SCADA system will indirectly change the business process. This study will review the way the organization responds to the implementation of new technology.

\section{LITERATURE STUDY}

Several studies have discussed SCADA technology. Edward, J. (2002) discusses the use of SCADA technology in oil well operations, where the impact on the economy and operations are only discussed in general. Furthermore, the limitation on the use of SCADA is limited to well operations.

Mochizuki et al. (2006) discusses the use of SCADA, called the real-time system. This real-time application must collaborate on three dimensions, namely human, processes, and technology itself. This research also discusses the advantages of using real-time monitoring, such as increased production, accelerated ROI, improved decision quality, improved HSE aspects, and reduced operating costs (OPEX), but again is not discussed in detail.

Camilleri et al. (2010) researched the benefits of using a real-time surveillance system and concluded that developing an online monitoring system to oil wells by lifting ESP can reduce loss of production opportunity due to unplanned shutdowns.

Waskito et al. (2019) researched the initiation of digital oil field applications and concluded that the implementation of oil field digitization could answer the challenges of managing offshore mature assets efficiently, reducing downtime optimize production, and reducing costs.

Priyadarshy (2017) studied the IoT revolution in the oil and gas industry and concluded that the implementation of IoT in oil and gas operating systems supports costeffective operation.

Shouping et al. (2019) developed a case study using SCADA as an operating system in a gas field project in China called an intelligent system. The development of intelligent gas fields creates several advantages, namely helping the ability to decide for exploration and development, 
optimizing production and speed of coordination, controlling security, and improving the company's business management. The ultimate goal is to support smooth operations, management efficiency, and safe operations. From the investment side, none of the literature discussed feasibility studies specifically about SCADA in full or on a partial scale.

Fonseca et al. (2017) discuss petroleum and gas project economics in the traditional way of NPV and IRR and calculates risk analysis and sensitivity analysis. The economic calculation is done with several economic simulations of the investment model offered.

Shaallan (2012) studied the impact of potential factors (risk analysis and uncertainty), these factors must be treated and determined at the level of quantity, then in monetary terms. This step is needed in economic feasibility studies that discuss and aim to achieve the specific monetary project value. Several techniques are used to calculate this: a sensitivity analysis, a probability analysis, a Monte Carlo simulation, and the methods of high discount rate and maximizing payback period.

Kinanthi (2017) conducted an investment feasibility assessment of information systems and concluded that the cost and benefit analysis method could be used in conducting investment feasibility studies.

Hussain (2018) conducted a 'critical review' of the leadership functions and involvement of workers in organizational change reviewed from change management and Lewin's analysis.

Based on the article above, this study tries to provide conclusions from several economic analyses, cost and benefit analysis by adding the sensitivity of oil price factors, production decline, and oil loss recovery due to the use of SCADA. Adding change management analysis from the inside responds to the plan of change from a manual system to SCADA.

\section{METHODOLOGY}

This study uses an integration method of study, where this method can provide a clear picture of a problem for more in-depth analysis. Figure 1 shows flow charts and research frameworks, and methods of this research activity.

This research starts from problem formulation, data collection, data analysis, and is completed with conclusions. This study's output provides an integrated analysis

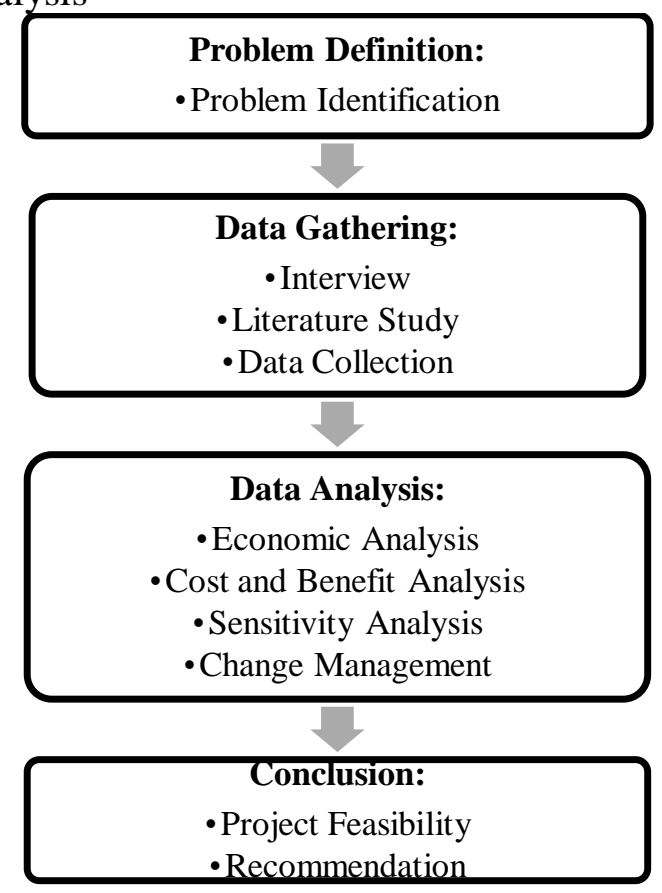

Figure 1. Flow Chart and Research Framework

of the investment in the implementation of the SCADA system in the full field, which is reviewed from the aspects of economic analysis, cost \& benefit analysis, and change management.

This study used primary data sources and secondary data. Primary data was obtained directly from the source as the first party by researchers on variables studied to achieve the goal (Sekaran \& Bougie, 2016). In this study, primary data was obtained from directly interviews of expert peoples from the companies that who involved in the operation of SCADA. In addition, SCADA-related data is also obtained from company data. While the secondary data is taken from literature 
studies related to the economic analysis, cost benefit analysis and change management model kurt lewin.

The data required in this study were:

1. Total oil and gas production of PHE OSES

2. The investment value of the SCADA system implementation

3. Costs incurred (Capex and Opex) compared to production produced (Bbl)

4. Utilization of SCADA in PHE OSES environment

5. Advantages and disadvantages of using SCADA obtained from secondary data and interview results of engineers and operations managers

\section{Cost and Benefit Analysis Methods}

The benefit of implementing this system was converted into value for money which was compared to the investment value that needed to be spent. From this analysis, it was expected that we would find out whether the value of profit generated could exceed the value of the investment or not.

This method is the most widely performed method of data-driven decisionmaking by many companies. Nevertheless, this method can also be applied in decisionmaking that is not related to a business or company. If, through the analysis it is found that the benefit is greater than the cost, then it can be considered that the decision is right. Conversely, if the cost outweighs the benefits, then the decision-making must be rethought.

\section{Economic Analysis Methods}

The economy's principle is how to get the most out of it with as little spending as possible. The company carries out this principle on an ongoing basis to continue growing and achieving the expected targets. One of the company's efforts to achieve this goal is to make the right decisions and policies in carrying out its operational activities, in line with technological updates in carrying out its operations, such as the installation of SCADA in the full field.
The data obtained was conducted using capital budgeting decision criteria such as NPV, IRR, PI, and payback period. From this analysis, we expected to know if this project was feasible to do when viewed from the economic side.

In the calculation of financial analysis, the revenue is a simulation of the amount of production compared to the investment cost of SCADA. The production amount is already a prediction of production decline that the implementation of SCADA has successfully held back.

\section{Change Management 'Lewin's model'}

Lewin developed the concept of force field analysis to analyze and understand the power of a change initiative. Lewin's three-step model refers to three concepts or phases, namely unfreezing movement - refreezing. For the SCADA project, the change management steps that we discuss there are several stages as follows:

a. How to identify the changes that would happen in the future after implementing the SCADA project. It is expected that the company can know the changes made and the impact in the future so that the company can understand the changes that occured and determine the strategy to be executed with this change.

b. How to plan so that changes in this stage will be analyzed in detail and considered factors that can be done so that the SCADA project will not harm all parties.

c. How the change's implementation will see the change itself, whether it is following expectations or not will be conducted through monitoring to help the company solve the problem if there is.

d. How to evaluate and hear the responses of employees working in the PHE OSES field. This stage will evaluate data received through interviews and direct communication with field 
employees who work in oil wells to be an input for management in the future.

\section{RESULT AND DISCUSSION}

Based on the results of interviews with key persons in PHE OSES, the production data collected are as follows:

1. Oil production year 2020: $7,775,000$ bbl

2. Gas production year 2020: 29,367 MMScf

3. Lowering natural oil production: $7 \% /$ year

4. Number of wells in operation: 399 wells

5. Operation Production Cost: USD 20/bbl

\section{Gross Split Scheme}

The SES block cooperation contract is a gross split scheme. This scheme is based on Permen ESDM No. 08 the Year 2017 on Gross Split Revenue Sharing Contract. This scheme uses the calculation of regional management revenue share taken into account between the government and oil and gas contractors. For this SES block, Pertamina gets a split of $68.5 \%$, while the government gets a split of $31.5 \%$.

\section{Oil Prices}

Oil produced from the SES working area is used for domestic needs in the country. The selling price of oil applied follows the ICP price wherein 2021 the ICP price is set at USD $44.5 / \mathrm{bbl}$.

\section{Production and Operation Losses}

In its operation, there are often dead wells that cause unplanned losses. Unplanned losses in 2019 amounted to 134,698 barrels caused by dead wells and required 1,575 man-days to revive them. Table 1 is a potential revenue loss due to unplanned losses.

Table 1. Actual Losses in 2019

\begin{tabular}{|l|c|}
\hline Event & $\begin{array}{c}\text { Actual } \\
\text { Losses 2019 } \\
\text { (USD/Year) }\end{array}$ \\
\hline Oil Losses & $6,061,410.00$ \\
\hline $\begin{array}{l}\text { Man-Hour Cost for Recovering } \\
\text { Down Time }\end{array}$ & $14,529,375.00$ \\
\hline $\begin{array}{l}\text { Fleet Charter Cost for } \\
\text { Recovering Down Time }\end{array}$ & $3,693,375.00$ \\
\hline
\end{tabular}

\begin{tabular}{|l|r|}
\hline $\begin{array}{l}\text { Fuel Usage Cost for Recovering } \\
\text { Downtime }\end{array}$ & $5,559,257.81$ \\
\hline $\begin{array}{l}\text { Well Repair Cost for } \\
\text { Recovering Downtime }\end{array}$ & $47,727,143.00$ \\
\hline
\end{tabular}

The investment plan of SCADA implementation in the PHE OSES field is as follows:Table 2. Budget Estimates for SCADA Implementation Projects

\begin{tabular}{|c|c|c|}
\hline \multicolumn{3}{|c|}{$\begin{array}{l}\text { (Source: PHE OSES Report) } \\
\text { Capex }\end{array}$} \\
\hline No & Year & USD \\
\hline 1 & 2021 & $2,715,623.67$ \\
\hline \multirow[t]{2}{*}{2} & 2022 & $1,042,765.84$ \\
\hline & Total (A) & $3,758,389.51$ \\
\hline \multicolumn{3}{|c|}{ Opex } \\
\hline $\mathrm{No}$ & Year & USD \\
\hline 1 & 2022 & $1,058,198.71$ \\
\hline 2 & 2023 & $949,549.70$ \\
\hline 3 & 2024 & $949,549.70$ \\
\hline 4 & 2025 & $949,549.70$ \\
\hline \multirow[t]{3}{*}{5} & 2026 & $928,126.81$ \\
\hline & Total (B) & $4,834,974.63$ \\
\hline & $\begin{array}{l}\text { Total } \\
(\mathrm{A}+\mathrm{B})\end{array}$ & $8,593,384.13$ \\
\hline
\end{tabular}

Some technical assumptions are used, namely:

1. The discount factor used is $11.33 \%$, taken from the economic data of other projects in PHE OSES.

2. The decrease in the annual production rate is fixed by $7 \%$.

3. The oil price used is the price based on ICP and assumed fixed during the projected SCADA implementation project (Indonesian crude oil price), which is USD $44.5 / \mathrm{bbl}$.

4. Use gross split scheme where $68.5 \%$ is Pertamina's revenue.

5. SCADA installation work will be completed by mid-2022.

6. The implementation of SCADA will reduce oil losses by $35 \%$ and will be felt after SCADA installation is completed (mid-2022).

The calculation of this projection is calculated until 2026, when it is likely that the system will be updated after 2026 .

\section{Economic analysis}

The results of SCADA investment economic calculation are as follows:

1. Internal Rate of Return 
The calculation result for IRR in this project is $15.31 \%$, which is higher than the discounted factor that has been set, which is $11.33 \%$.

2. Net Present Value

The resulting NPV figure is USD $353,220.91$. The resulting NPV shows a positive number.

3. Profitability Index

The PI value obtained from this project is 1.10 , where this value is higher than 1.

4. Discounted Payback Period

Discounted PB generated is for 65.26 months or 5 years 5.68 months.

When viewed from the calculation results above, it can be said that this project can be accepted following the criteria of capital budgeting because it shows IRR > discounted factor, NPV $>1$, and PI $>1$.

\section{Sensitivity Analysis Capital Budgeting}

NPV sensitivity test is conducted against several factors: oil price, decline rate, and oil losses recovery.

Table 3. Sensitivity Test Input

\begin{tabular}{|l|c|c|c|c|c|}
\hline \multirow{2}{*}{ Parameter } & \multicolumn{5}{|c|}{ Sensitivity } \\
\cline { 2 - 6 } & $-20 \%$ & $-10 \%$ & $0 \%$ & $+10 \%$ & $+20 \%$ \\
\hline $\begin{array}{l}\text { Oil Price } \\
\text { (USD/bbl) }\end{array}$ & 35.60 & 40.05 & 44.50 & 48.95 & 53.40 \\
\hline $\begin{array}{l}\text { Production } \\
\text { Decline } \\
\text { (\%/Year) }\end{array}$ & 8.40 & 7.70 & 7.00 & 6.30 & 5.60 \\
\hline $\begin{array}{l}\text { Oil Losses } \\
\text { Recovery } \\
(\%)\end{array}$ & 28.00 & 31.50 & 35.00 & 38.50 & 42.00 \\
\hline
\end{tabular}

Table 4. NPV Sensitivity Test Results to Oil Price, Decline Rate, and Oil Losses Recovery

\begin{tabular}{|c|c|c|c|c|c|}
\hline \multirow{2}{*}{ Parameter } & \multicolumn{5}{|c|}{ NPV (USD)x1000 @ Sensitivity } \\
\hline & $-20 \%$ & $-10 \%$ & $0 \%$ & $+10 \%$ & $\begin{array}{c}+20 \\
\%\end{array}$ \\
\hline \multirow{2}{*}{$\begin{array}{l}\text { Oil Price } \\
\text { (USD/bbl) }\end{array}$} & $(447.9)$ & $(47.3)$ & 353.2 & 753.7 & $\begin{array}{l}1,154 \\
.3 \\
\end{array}$ \\
\hline & $-227 \%$ & 110 & $0 \%$ & 1 & $227 \%$ \\
\hline \multirow{2}{*}{$\begin{array}{l}\text { Production } \\
\text { Decline } \\
\text { (\%/Year) }\end{array}$} & 239 & 296 & 353 & 411 & 470.0 \\
\hline & $-32 \%$ & 160 & 0 & $16^{\circ}$ & $33 \%$ \\
\hline \multirow{2}{*}{$\begin{array}{l}\text { Oil Losses } \\
\text { Recovery } \\
(\%)\end{array}$} & $(447.9)$ & $(47.3)$ & 353.2 & 753.7 & $\begin{array}{l}1,154 \\
.3 \\
\end{array}$ \\
\hline & $-227 \%$ & $-113 \%$ & $0 \%$ & $113 \%$ & $227 \%$ \\
\hline
\end{tabular}

From Table 4 above, it can be concluded that NPV is very sensitive to oil price and oil losses recovery resulting from the implementation of this SCADA, with a reduction in the value of oil price and oil losses recovery by $10 \%$ causing the NPV of this project to be reduced by $113 \%$ $(>100 \%)$. While with a decrease in production decline of $10 \%$, NPV reduction is only $16 \%$.

\section{Cost and Benefit Analysis}

From the interviews with the engineer, here are the benefits obtained from the SCADA implementation project:

1. Increased production results due to monitoring and analysis of wells conducted online and in real-time. (1)

2. Reduced downtime due to production disruptions at oil wells. (2)

3. ESP lifetime improvements. (3)

4. Improved response to abnormal condition of wells' parameters. (4)

5. Optimization of operational resources in the field, such as man-power arrangements and operational boat schedules. (5)

6. Improved performance of the company's HSE with reduced exposure to workers to the risk of direct job harm. (6)

\section{Identification of Benefits and Costs}

From the six benefit points obtained from the interview results, it will be grouped as follows:

1. Direct Benefit: (2), (4), and (5)

2. Indirect Benefit: (1), and (3)

3. Intangible Benefit: (6)

4. Competitive Benefit: -

While the costs incurred in this SCADA implementation project are direct costs (for capital expenditure) and indirect costs (for SCADA operational expenses and production costs).

\section{Benefit and Cost Value}

The actual loss data in 2019 is being used to determine the value of benefits. In 2019 , there were accumulative production losses of 134,698 bo caused by shut-in 
wells which needed 1,575 man-days to revive them.

From the actual losses data in Table 1, the assumption of reduction in losses and downtime is $35 \%$ if we use SCADA. The resulting value is the value of the benefit for the calculation of this analysis, and the benefit begins to be felt when the SCADA installation has been completed (mid2022). This CBA projection will be calculated until 2026.

Table 5. Benefit and Cost Value

\begin{tabular}{|l|l|l|}
\hline \multirow{2}{*}{$\begin{array}{l}\text { Direct } \\
\text { Benefit }\end{array}$} & Oill Losses & $\begin{array}{l}\text { Losses Recovery 35\% } \\
\text { (USD/Year) }\end{array}$ \\
\cline { 2 - 3 } & Man-Hours & $5,085,493.50$ \\
\cline { 2 - 3 } & Fleet Charter & $1,292,681.25$ \\
\hline \multirow{2}{*}{$\begin{array}{l}\text { Indirect } \\
\text { Benefit }\end{array}$} & Fuel Usage & $1,945,740.23$ \\
\hline & Well Repair & $16,704,500.05$ \\
\hline & Total & $27,149,696.28$ \\
\hline \multirow{2}{*}{$\begin{array}{l}\text { Direct } \\
\text { Cost }\end{array}$} & Capex & \\
\hline \multirow{2}{*}{$\begin{array}{l}\text { Indirect } \\
\text { Cost }\end{array}$} & $\begin{array}{l}\text { SCADA } \\
\text { Opex }\end{array}$ & USD $3,758,3834,974.63$ \\
\cline { 2 - 3 } & $\begin{array}{l}\text { Production } \\
\text { Costs }\end{array}$ & USD 20/bbl \\
\hline
\end{tabular}

\section{Cost and benefit comparison}

After identifying the value of cost and benefit, NPV value calculation compares the cost and benefit. Appendix 1 is the result of NPV calculation. From the calculation, a positive NPV resulted in a benefit comparison of 3.03. When viewed from the CBA side, this SCADA implementation project is a project that deserves to be implemented.

\section{Cost \& Benefit Analysis Sensitivity Test}

A sensitivity test of improved value improvement or percentage reduction of downtime/losses to NPV was conducted. The sensitivity test results can be seen in Figure 2 below.

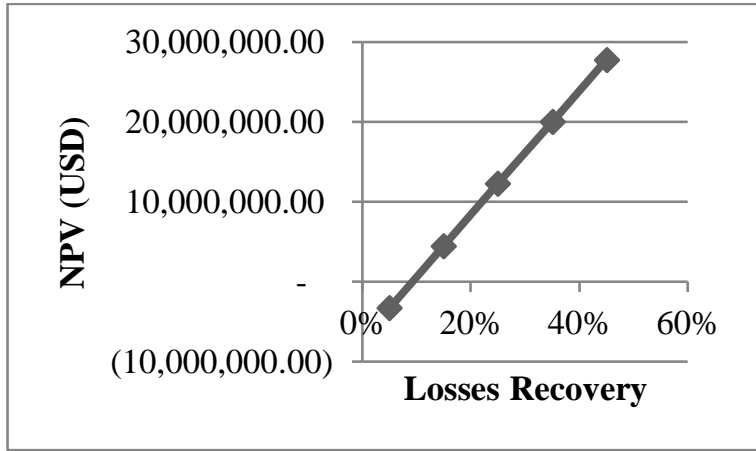

Figure 2. NPV Chart Against Losses Recovery

From figure 2, the NPV shows the number 0 when the benefit of improvement is at 3.36. So, it can be interpreted that the value benefit generated will be equal to the value cost incurred if the benefits of improvement or improvement of SCADA implementation can reduce losses by $9.28 \%$.

Kurt Lewin's Change Management Strategy Implementation

Based on the results of interviews conducted to the company expert peoples who involved in the operation of SCADA, there found 19 (nineteen) conclusions of SCADA implementation strategy were obtained. It can then be explained through the three stages of Kurt Lewin's method; unfreezing, movement, and refreezing. Unfreezing is a process of raising the awareness of all parties in PHE OSES of the need for a change with SCADA implementation. Movement is action to strengthen the driving force and weaken all obstacles to implementing SCADA in PHE OSES. Moreover, refreezing is the process of bringing the situation in PHE OSES back to a new balance.

According to Lewin, this mapping is done by matching each of SCADA's objectives, impacts, and investment benefits with change management measures. The results of the mapping can be seen in Table 6 :

$\begin{array}{lcr}\text { Table } & 6 . & \text { Unfreezing-Movement- } \\ & \text { Refreezing in } & \text { SCADA } \\ & \text { Implementation Strategy }\end{array}$




\begin{tabular}{|c|c|c|c|c|}
\hline \multirow{2}{*}{ No. } & \multirow{2}{*}{ SCADA Implementation Strategy } & \multicolumn{3}{|c|}{$\begin{array}{l}\text { Change Management Methods According } \\
\text { to Lewin }\end{array}$} \\
\hline & & Unfreezing & Movement & Refreezing \\
\hline 1 & $\begin{array}{l}\text { Explaining the value of Technology } \\
\text { benefits derived from the } \\
\text { implementation ofSCCustem }\end{array}$ & $\mathbf{v}$ & & \\
\hline 2 & $\begin{array}{l}\text { Socializizing the ease of SCADA } \\
\text { implementation }\end{array}$ & $\mathbf{v}$ & & \\
\hline 3 & $\begin{array}{l}\text { Socializing the importance of } \\
\text { SCADA implementation to all users }\end{array}$ & $\mathbf{v}$ & & \\
\hline 4 & $\begin{array}{l}\text { Creating a stand-alone team that } \\
\text { manages SCADA systems }\end{array}$ & $\mathrm{v}$ & & \\
\hline 5 & $\begin{array}{l}\text { Creating a team with selected } \\
\text { emploves to sumport changer }\end{array}$ & $\mathbf{v}$ & & \\
\hline 6 & $\begin{array}{l}\text { Bringing in new and expericenced } \\
\text { employees to accelerate SCDDA } \\
\text { implementation. }\end{array}$ & $\mathbf{v}$ & & \\
\hline 7 & $\begin{array}{l}\text { Strengthening PHE OSES } \\
\text { management support }\end{array}$ & & $\mathrm{v}$ & \\
\hline 8 & $\begin{array}{l}\text { Acting as a a pioneer in Pertamina in } \\
\text { the instaltaion of SADA } \\
\text { thoroughly in production facilities } \\
\text { (Well production }\end{array}$ & & $\mathbf{v}$ & \\
\hline 9 & $\begin{array}{l}\text { Instruction from Pertamina as a } \\
\text { holding company to use industrial } \\
\text { technology } 4.0\end{array}$ & & $\mathrm{v}$ & \\
\hline 10 & $\begin{array}{l}\text { Conducting regular training on } \\
\text { SCADA with all parties involved }\end{array}$ & & $\mathbf{v}$ & \\
\hline 11 & $\begin{array}{l}\text { Improving employee competency } \\
\text { capabilities ivit technology in } \\
\text { SCADA development }\end{array}$ & & $\mathbf{v}$ & \\
\hline 12 & $\begin{array}{l}\text { Continuing to socialize the } \\
\text { importance of SCADA } \\
\text { implementation to all employees }\end{array}$ & & $\mathbf{v}$ & \\
\hline 13 & $\begin{array}{l}\text { Communicating the purpose of } \\
\text { SCDDA implementation to all } \\
\text { employees in the company }\end{array}$ & & $\mathbf{v}$ & \\
\hline 14 & $\begin{array}{l}\text { Strtengthening good relationships } \\
\text { with SCADA vendors and subcont }\end{array}$ & & $\mathrm{v}$ & \\
\hline 15 & $\begin{array}{l}\text { Rewarding any employee who can } \\
\text { comply quickly with SCADA } \\
\text { requirements }\end{array}$ & & & $\mathbf{v}$ \\
\hline 16 & $\begin{array}{l}\text { Periodically evaluating SCADA } \\
\text { implementation }\end{array}$ & & & $\mathbf{v}$ \\
\hline 17 & $\begin{array}{l}\text { Supervising and evaluating SCADA } \\
\text { implementation }\end{array}$ & & & $\mathbf{v}$ \\
\hline 18 & $\begin{array}{l}\text { Learning from other companies that } \\
\text { have inplemented SCADA }\end{array}$ & & & $\mathbf{v}$ \\
\hline 19 & $\begin{array}{l}\text { Implementing all operations and } \\
\text { cctivitie that wit vour eeds }\end{array}$ & & & $\mathbf{v}$ \\
\hline
\end{tabular}

Figure 3 shows the drivers or driving forces and obstacles to change with the implementation of SCADA thoroughly in the area of PHE OSES operations.

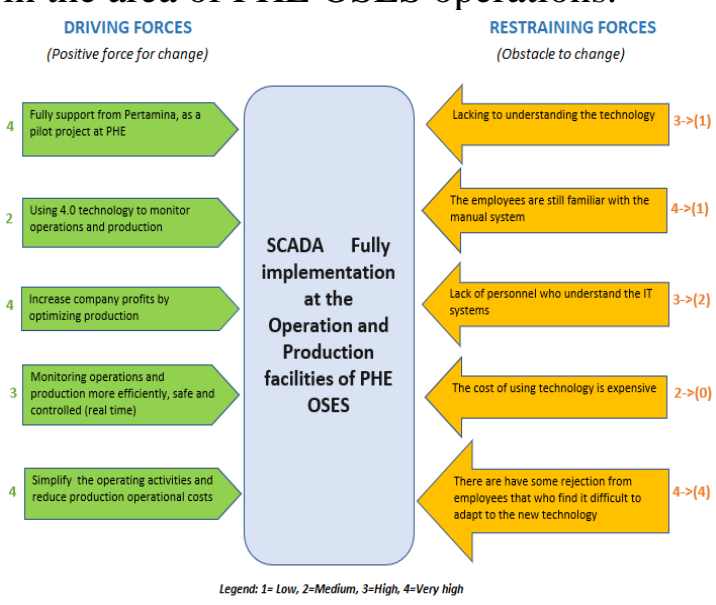

Figure 3. Driving Forces and Restraining Forces Implementation SCADA

\section{Driving Forces}

From the diagram above, concluded several factors supported the implementation of SCADA in PHE OSES, namely: the company received full support from Pertamina's holding company as a pioneer in using SCADA as a monitoring system facilitated by operations and production. With this, PHE OSES already runs technology or industry 4.0 in its business. The implementation of SCADA also increases the company's profits with the increasing production of old oil wells that impact the company's direct profits. SCADA helps operations and production activities become more efficiently safe and controlled where workers in production facilities do not have to frequently conduct checks to the production field that were always done in the past before SCADA. This will also have a direct impact by reducing the company's operational costs. With SCADA technology, the monitoring system can be done in real-time and can be done anywhere without having to come directly to the location.

\section{Restraining Forces}

The implementation of SCADA also gets some inhibitory factors that become challenges for management. There are still negative thoughts and responses from employees. Some employees who still lack understanding of web-based monitoring systems and some employees who are not used to using technology in work and prefer to work manually will undoubtedly be an obstacle if not resolved. The lack of professionals who understand SCADA is also an obstacle that needs to be resolved. SCADA technology implementation is also not cheap because the cost of procurement of goods and equipment is prohibitive. Of course, there needs to be a long-term cost calculation from management to maintain SCADA technology throughout production facilities.

To reduce or eliminate restraining forces at SCADA implementation, it is necessary to conduct mitigation as follows: a. Training

Conduct training to all employees of production facilities so that all employees can understand how to use and monitor the operations and 
production of PHE OSES by using SCADA technology.

b. Recruit Experts

To accelerate the implementation of SCADA, it is necessary to recruit new employees who better understand the concept of using technology in work to help accelerate the implementation of SCADA.

c. Socialization

Continuous socialization of SCADA implementation is required to all parties about the importance of this SCADA method to be implemented throughout PHE OSES production facilities. Management can also discuss directly with each employee and actively explain all questions or clarify matters that employees do not yet understand.

\section{CONCLUSION}

From the calculations obtained, this project has an IRR of $15.31 \%$ (greater than the discount factor $(11.33 \%)$ ), a positive NPV value of USD 353,220.91, a PI value of 1.10 (> 1), and a discounted payback period of 65.26 months. Based on these figures, the project meets the criteria of capital budgeting.

The NPV sensitivity test was conducted on oil price, production decline rate, and oil losses recovery. The project is susceptible to oil prices and oil losses recovery, with a decrease in oil prices and oil losses recovery by $10 \%$; the NPV of this project will also fall by $113 \%$ and NPV to negative.

By reducing $35 \%$ of production and operation losses because of SCADA implementation, the comparison between benefits and costs in this project is 3.03 $(>1)$, so this project deserves to continue.

From the NPV sensitivity test on losses recovery, it was determined that NPV was worth 0 or the value of benefit and cost would be the same if this SCADA implementation project could only reduce production and operation losses by $9.28 \%$.
Training, socialization, and the hiring of experts will play a vital role in the success of SCADA investment. Thus, SCADA investment is feasible to continue, but this research has limitations insomuch as the assumptions used in the investment delivery process run smoothly according to economic calculations.

\section{ADVICE}

Further research recommendations are to ensure that the project runs on an OTOBOSOR (On Time On Budget On Scope and On Return). These is very important due to the economic calculated of those investment there is included the time factor as part of the calculation of return on investment.

This study implemented a live interview with a question-and-answer method with expert person concerned with the implementation of SCADA in PHE OSES. In the next study can use questionnaires according to the organization or company of the research to be taken.

\section{REFERENCES}

Al-Mutawa, S. A., Saleem, E., Anthony, E., Moricca, G., Kain, J., \& Saputelli, L. (2013). Digital Oilfield Technologies Enhance Production in ESP Wells. SPE Kuwait Oil and Gas Show and Conference. Mishref, Kuwait: Society of Petroleum Engineers.

Bailey, D., \& Wright, E. (2003). Practical Scada for Industry. Oxford: Newnes.

Berger, T., \& Crompton, J. (2015). Change Management in The Digital Oilfield: We Know We Need it, But Where's the Roadmap? SPE Digital Energy Conference and Exhibition. Woodlands, Texas, USA: Society of Petroleum Engineers.

Boardman, A. E., Greenberg, D. H., Vining, A. R., \& Weimer, D. L. 
(2014). Cost-benefit analysis: concepts and practice (Pearson New International ed.). Harlow, Essex, England: Pearson Education Limited.

Camilleri, L. A., \& Macdonald, J. (2010). How 24/7 Real-Time Surveillance Increases ESP Run Life and Uptime. SPE Annual Technical Conference and Exhibition. Florence, Italy: Society of Petroleum Engineers.

Chowdhury, S. (2016). Optimization and Business Improvement Studies in Upstream Oil and Gas Industry. Hoboken, New Jersey: John Wiley \& Sons, Inc.

Daneels, A., \& Salter, W. (1999). What Is Scada? International Conference on Accelerator and Large Experimental Physics Control System. Trieste, Italy. Retrieved from https://cds.cern.ch/record/532624/ files/mc1i01.pdf

Edwards, J. J. (2002). Gas well production optimization with remote performance monitoring. Canadian International Petroleum Conference. Calgary: Petroleum Society of Canada.

Fonseca, M. N., Pamplona, E. O., Junior, P. R., \& Valerio, V. E. (2017). Feasibility analysis of the development of an oil field: a real options approach in a production sharing agreemen. Revista Brasileira de Gestão de Negócios, 19(66), 574-593.

Hussain, S. T., Lei, S., Akram, T., Haider, M. J., Hussain, S. H., \& Ali, M. (20017). Hussain, S. T., Lei, S., Akram, T., Haider, M. J., Hussain, S. H., \& Ali, M. (2018). Kurt Lewin's change model: A critical review of the role of leadership and employee involvement in organizational change. Journal of
Innovation \& Knowledge, 3(3), 123-127.

Kinanthi, R. A. (2017). Analisis Kelayakan Investasi Sistem Informasi Pendistribusian Produk Menggunakan Metode Cost Benfit Analysis Pada PT. Guna Atmaja Jaya. Doctoral dissertation, Institut Teknologi Sepuluh Nopember.

Mochizuki, S., Saputelli, L., Kabir, C., Cramer, R., Lochmann, M., Reese, R., . . . Escorcia, A. (2006, November). Real-Time Optimization: Classification and Assessment. SPE Production \& Operations, 21(4).

Parinno, R., Kidwell, D., \& Bates, T. (2015). Fundamentals of Corporate Finance (3rd ed.). John Wiley \& Sons.

Priyadarshy, S. (2017). Iot revolution in oil and gas industry. Internet of Things and Data Analytics Handbook.

Sekaran, U., \& Bougie, R. (Research methods for business). 2016 (7th ed.). Sussex, UK: John Wiley \& Sons.

Shaallan, H. Y. (2012). Economic Feasibility Study for Petroleum Projects (Practical Aspects). Journal of Petroleum Research \& Studies, 261(5).

Shallan, H. Y. (2012). Economic Feasibility Study for Petroleum Projects (Practical Aspects). Journal of Petroleum Research and Studies, 3(1), 26-47.

Shouping, W., Xinling, P., Lu, Q., Long, F., Jiang, Y., \& Meng, Y. (2019, June 1). Design and implementation of the overall architecture of the Puguang intelligent gas-field project. Natural Gas Industry B, 6(3), 262-271.

Thompson, J., Arthur, A., Peteraf, M. A., Gamble, J. E., \& Strickland, A. J. (2018). Crafting \& executing 


$$
\begin{aligned}
& \text { strategy, the quest advantage, } \\
& \text { concepts and cases (21st ed.). } \\
& \text { New York: McGraw-Hill. }
\end{aligned}
$$

Waskito, L. B., Vidrianto, M., \& Cahyoniarso, B. (2019). Initiate Digital Oil Field Application at Mature Offshore Oil Field in South East Sumatera, Indonesia. Asia Pacific Oil \& Gas Conference and Exhibition. Bali: Society of Petroleum Engineers.

endix 1. NPV Calculations to Compare Costs and Benefits

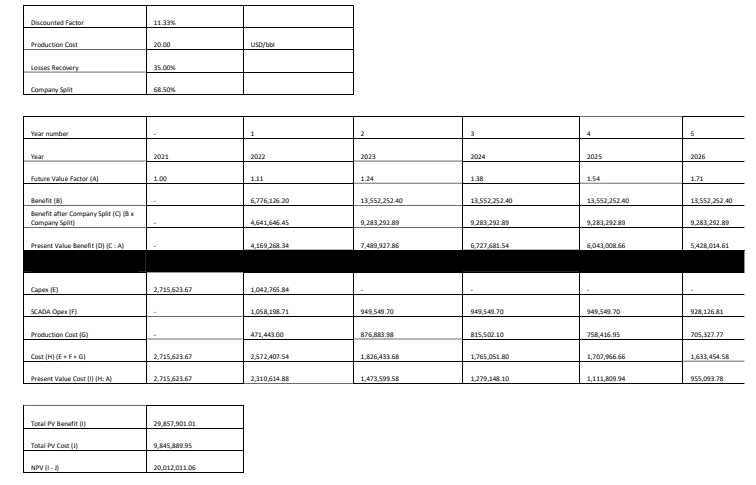

